\title{
Study of PHAs (polyhydroxyalkanoates) production from activated sludge
}

\author{
D. He, B. B. Zhang, Y. F. Tsang \& H. Chua \\ Department of Civil and Structure Engineering, \\ Hong Kong Polytechnic University, Hong Kong, P.R. China
}

\begin{abstract}
Sludge deposition is of high concern for managers of wastewater treatment plants due to limited landfill space and increases in deposition fees. Reduction of the amount of sludge can benefit a plant's operational cost. In activated sludge, numerous bacteria synthesise and accumulate polyhydroxyalkanoates (PHAs). PHAs can be completely biodegraded to water and carbon dioxide, and have similar properties to conventional plastic. So, PHAs have been recognized as good candidates for plastics. Thus, production of PHAs can reduce sludge amount and also have environmentally-friendly effects. However, their high price compared with conventional plastics has limited their use in a wide range of applications. In this study, we optimized conditions to produce PHAs. Activated sludge bacteria from a conventional wastewater treatment process were induced to accumulate PHAs under different carbon-nitrogen $(\mathrm{C}: \mathrm{N})$ ratios. Both the highest net cell growth and polymer production yield were achieved under a C:N ratio of 96. Moreover, carbon source is another important factor in synthesis. The composition of the polymer accumulated was dependent on the valeric acid $\left(\mathrm{C}_{5}\right)$ content in the feed.
\end{abstract}

Keywords: activated sludge, polyhydroxyalkanoates (PHAs), carbon-nitrogen ratios, carbon source.

\section{Introduction}

Plastic materials have become an integral part of contemporary life because of their many desirable properties, including their duralibity, flexibility and resistance. However, many artificial polymers are found to be harmful to the environment due to the non-biodegradable properties, which means they are not easily decomposed in nature by microorganisms (Huang et al. [1]). So there is a 
sustained and substantial interest of biodegradable materials to supplement or replace the existing need of non-biodegradable ones. Polyhydroxyalkanoates (PHAs) represent a kind of biopolymers. PHAs have similar unique physical and chemical characters to petroleum-derived plastics. They can also be completely degraded to water and carbon dioxide. It's biodegradable and biocompatible characteristics make them a green alternative to petrochemical-derived polymers.

Due to these unique characteristics of PHAs, various kinds of bacterial strains have been tested for their PHAs production capability. Up to the present, there are more than 300 different microorganisms which can synthesize PHAs. Several of these, such as Ralstonia eutropha, Alcaligenes latus, Azotobacter vinelandii, and several strains of methylotrophs and recombinant Escherichia coli are being studied because of high productivity (Lee [2]). The PHAs content achieved by Alcaligenes latus can reach $88 \%$ (Wang and Lee [3]), and recombinant Escherichia coli has been reported to reach $76 \%$ of cell dry weight (Lee and Chang [4]). Although high PHAs content can be achieved by pure culture, the cost of PHAs production is still too high for PHAs to become a competitive commodity plastic material. For this reason, a novel PHAs production strategy should be studied. Thus, this novel technique can produce and recover PHA from activated sludge to provide a potentially inexpensive source of biodegradable plastics. This method can also reduce the quantity of excess sludge that requires further treatment. In our study, the effect of $\mathrm{C}: \mathrm{N}$ ratio was investigated to enhance PHAs production yield. To cater for possible application, another experiment was set up to find a relationship between carbon source and polymer composition.

\section{Material and methods}

\subsection{Biological reactor system set-up}

Activated sludge was collected from municipal wastewater treatment plants in Tai Po (Hong Kong). The activated sludge was transferred and cultivated in a laboratory scale sequencing batch reactor (SBR) of 20-L effective volume and 1.5 days hydraulic retention time (HRT). The reactor was operated in a sequencing batch mode with a 2-hour for anaerobic stage, 4-hour for aerobic stage and settlement 1 hour, and then another 1 hour for drawing effluent and refilling of synthetic wastewater. The system was performed daily for three consecutive cycles. The reactor was operated at room temperature $\left(22-25^{\circ} \mathrm{C}\right)$.

\subsection{Inoculums and substrates}

The synthetic substrate solution had $400 \mathrm{mg} \mathrm{COD} / \mathrm{L}$ and $16.95 \mathrm{mg} \mathrm{P} / \mathrm{L}$, and was prepared with K2HPO4 (3.7mg/L), $\left(\mathrm{NH}_{4}\right)_{2} \mathrm{SO}_{4}(200 \mathrm{mg} / \mathrm{L}), \quad \mathrm{MgSO}_{4} \cdot 7 \mathrm{H}_{2} \mathrm{O}$ $(20 \mathrm{mg} / \mathrm{L})$ and mineral salts solution $(2.4 \mathrm{~mL} / \mathrm{L})$. The mineral salts solution was composed of $\mathrm{FeCl}_{3}(28.4 \mathrm{mg} / \mathrm{L}), \mathrm{H}_{3} \mathrm{BO}_{4}(4 \mathrm{mg} / \mathrm{L}), \mathrm{CoCl}_{2} \cdot 6 \mathrm{H}_{2} \mathrm{O}(8 \mathrm{mg} / \mathrm{L})$, $\mathrm{MnCl}_{2} \bullet 2 \mathrm{H}_{2} \mathrm{O}(0.3 \mathrm{mg} / \mathrm{L}), \mathrm{Al}_{2}\left(\mathrm{SO}_{4}\right)_{3} \bullet 18 \mathrm{H}_{2} \mathrm{O}(2.2 \mathrm{mg} / \mathrm{L}), \mathrm{NaSiO}_{3} \bullet 5 \mathrm{H}_{2} \mathrm{O}(4 \mathrm{mg} / \mathrm{L})$, $\mathrm{ZnSO}_{4} \cdot 7 \mathrm{H}_{2} \mathrm{O}(2 \mathrm{mg} / \mathrm{L})$ and Thiamine hydrogen chloride $(8 \mathrm{mg} / \mathrm{L})$. 


\subsection{Analysis}

Residual carbon concentration was presented as carbon oxygen demand (COD) (Standard Code:5220), total kjeldahl nitrogen (TKN) (Standard Code:4500Norg), dissolved oxygen (DO), $\mathrm{pH}$ and dry cell mass (Standard Code:2540D). The TKN was determined using a Tecator Autoanalyzer (KJELTEC AUTO 1030 ANALYZER). The activated sludge sample was first centrifuged and only the supernatant was taken for TKN analysis. DO was measured by DO meter (YSI Model No.55). The pH was monitored by $\mathrm{pH}$ meter (ORION Model EA 940). Mixed liquor suspended solids (MLSS) and mixed liquor volatile suspended solids (MLVSS) were measured according to Standard Methods (Clesceri et al. [5]). Analysis of PHA was used the gas chromatographic method (GC). The procedure was repeated for the standard $\mathrm{PHB}$ and $\mathrm{P}(3 \mathrm{HB}-\mathrm{co}-3 \mathrm{HV})$ (Jan et al. [6]).

\subsection{Extraction of the polymer}

The activated sludge from the SBR was centrifuged at $3000 \mathrm{rpm}$ for 15 minutes. The sludge was then dried in an oven at $60^{\circ} \mathrm{C}$ and ready for extraction. The dried sludge was transferred into the thimble in the fraction distillation and treated with 5 vol. chloroform at $80^{\circ} \mathrm{C}$ overnight. Then, the extract was concentrated to about $20 \mathrm{~mL}$ by using a rotary evaporator. Finally, the polymers were precipitated by mixing with methanol $(1: 10 \mathrm{v} / \mathrm{v})$ and the products were filtered out by simple filtration. The sample was put on an aluminum foil and then dried in an oven at $70^{\circ} \mathrm{C}$ for 24 hours until it was a constant weight. The weights of the extracted polymers were measured to determine the productivity.

\section{Results and discussion}

\subsection{Effect of C:N ratio on PHA production}

After the reactor was operated to attain a stable condition under the $\mathrm{C}: \mathrm{N}$ ratio of 24 , the supplied nitrogen concentration in the wastewater was reduced to result in $\mathrm{C}: \mathrm{N}$ ratio of 48,96 and 144 , creating different degrees of nutrient deficiency. Because prolonged nitrogen deficiency would adversely affect microbial growth, for each $\mathrm{C}: \mathrm{N}$ ratio above 24 , an intermittent nitrogen feeding was required after every 4 cycles to enhance cell growth. Activated sludge samples of each $\mathrm{C}: \mathrm{N}$ ratio were periodically taken and investigated from the reactor during the 2-hour aeration period in a randomly selected operation cycle for analysis.

After achieving stable operation conditions, a sample was drawn for every 30 minutes within a 2-hour reaction period. Figure 1 shows the microbial cell mass and polymer production in the reactor liquor during the 2-hour reaction time with a $\mathrm{C}: \mathrm{N}$ ratio of 24 . As the reaction time proceeded, the cell mass in the system increased from 22.24 to $24.03 \mathrm{~g}$, giving net cell growth of $1.79 \mathrm{~g}$. The polymer content increased from 0.10 to $0.21 \mathrm{~g}$.

After finishing process of $\mathrm{C}: \mathrm{N}$ ratio of 24 , the $\mathrm{NH}_{4} \mathrm{Cl}$ concentration in the medium was reduced to $0.08 \mathrm{~g} / \mathrm{L}$, resulting in a $\mathrm{C}: \mathrm{N}$ ratio of 48 . It was found that 


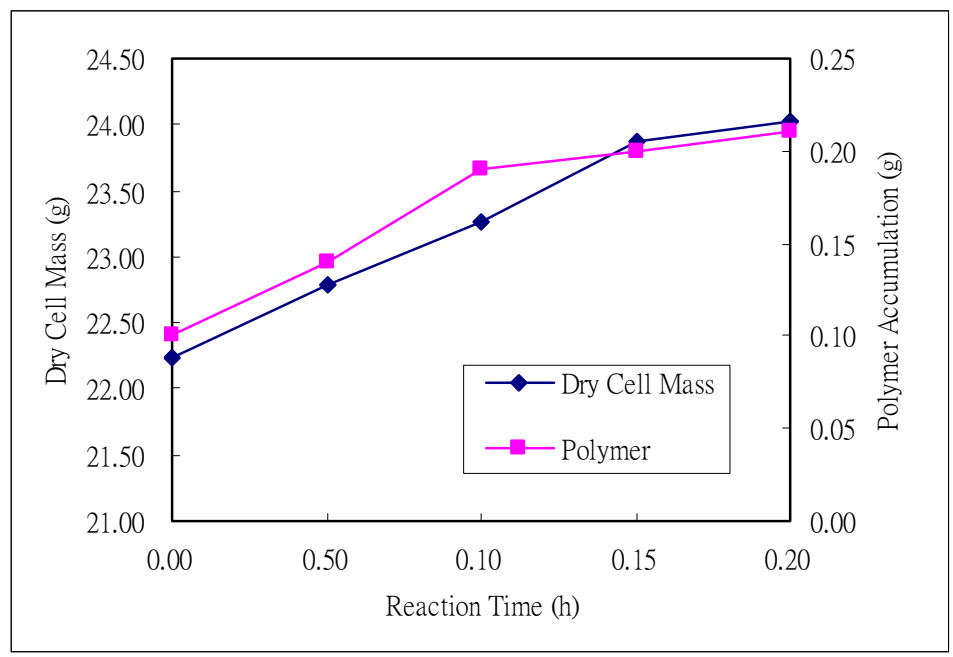

Figure 1: $\quad$ Cell mass growth and polymer accumulation at C:N ratio of 24 .

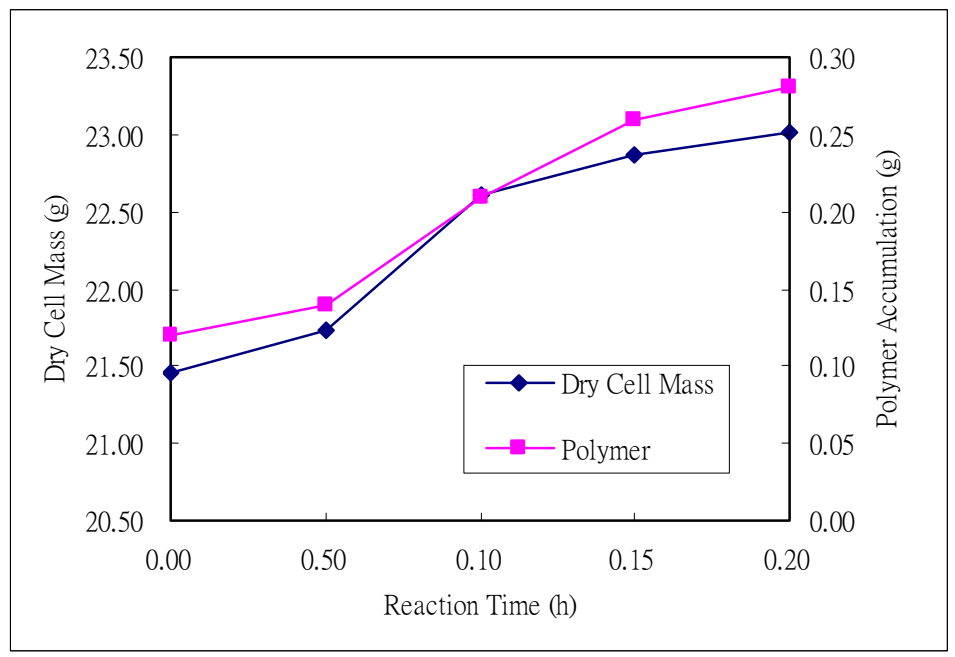

Figure 2: Cell mass growth and polymer accumulation at C:N ratio of 48 .

when the $\mathrm{C}: \mathrm{N}$ ratio was 48 , the net cell growth decreased to $1.57 \mathrm{~g}$ and the storage polymer accumulation increased to $0.16 \mathrm{~g}$ (Figure 2).

To create a C:N ratio of $96, \mathrm{NH}_{4} \mathrm{Cl}$ was further reduced to $0.04 \mathrm{~g} / \mathrm{L}$. When the $\mathrm{C}: \mathrm{N}$ ratio was increased to 96 , the accumulation of $0.23 \mathrm{~g}$ of intracellular storage polymer was more than that when the $\mathrm{C}: \mathrm{N}$ ratio was 24 and 48 , while the net cell growth was $0.96 \mathrm{~g}$ which was lower than that when the C:N ratio was 24 and 48 (Figure 3). The reason is possibly that the reactor entered into the stage of nitrogen-deficiency which is favourable for polymer accumulation. 


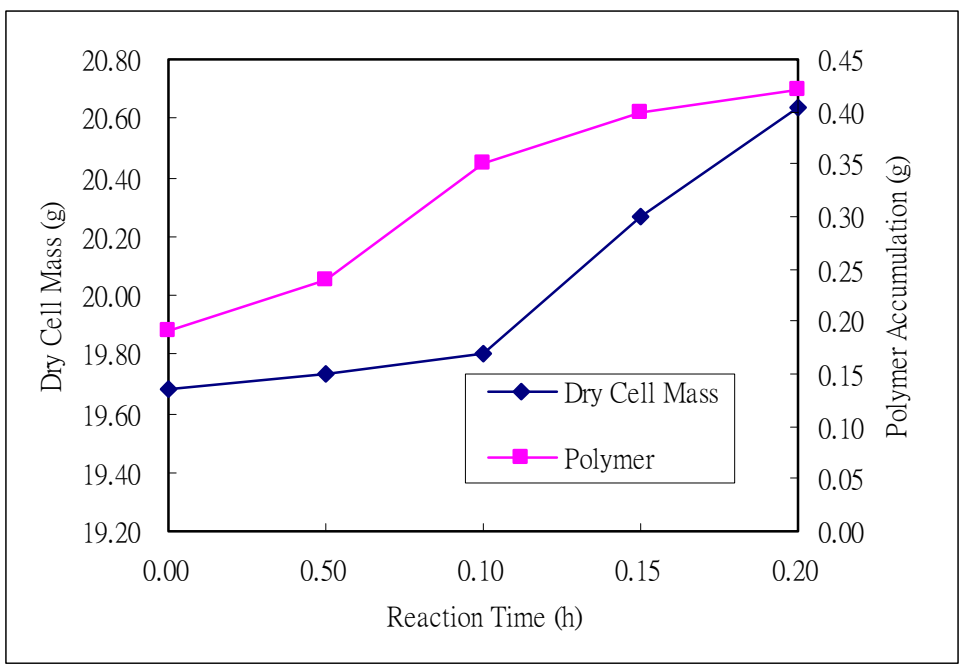

Figure 3: $\quad$ Cell mass growth and polymer accumulation at $\mathrm{C}: \mathrm{N}$ ratio of 96.

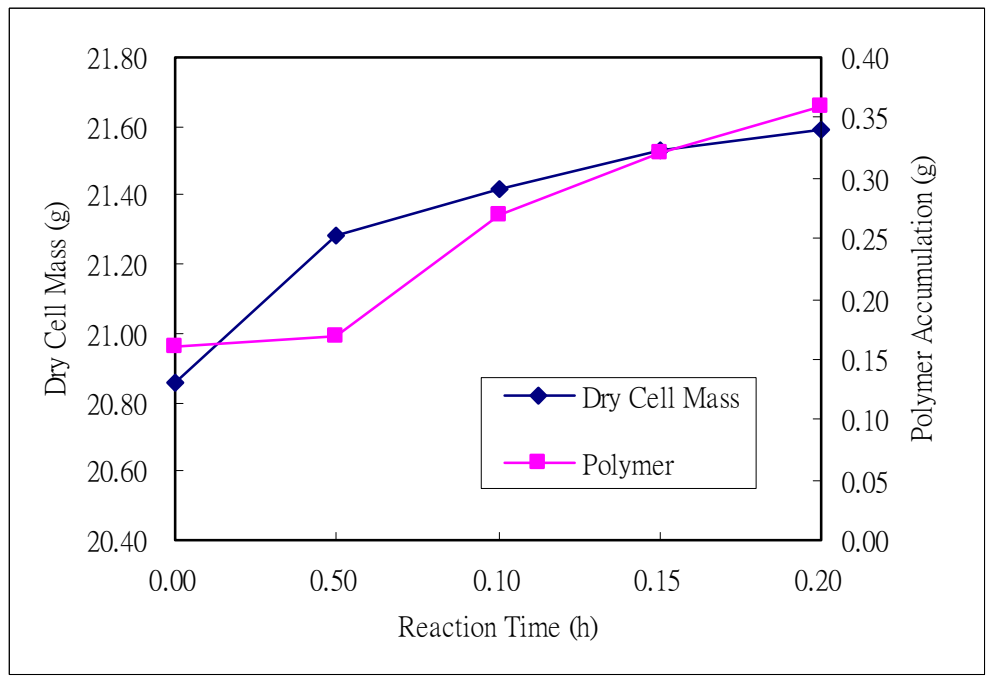

Figure 4: Cell mass growth and polymer accumulation at C:N ratio of 144.

The C:N ratio was further increased to 144 . Similar observations were made. Figure 4 shows the microbial cell mass and accumulation of polymer at $\mathrm{C}: \mathrm{N}$ ratio of 144. However, the net cell growth further decreased to $0.73 \mathrm{~g}$ and accumulation of $0.20 \mathrm{~g}$ polymer was less than when the C:N ratio was 96 .

The net cell growth, polymer accumulation and product yields under four different C:N ratios are summarized in Table 1. It was found that an increase in $\mathrm{C}: \mathrm{N}$ ratio from 24 to 144 resulted in a decline in net cell growth from 1.79 to 
$0.73 \mathrm{~g}$, but an increase in net polymer accumulation from 0.11 to $0.20 \mathrm{~g}$. This indicated that the nitrogen-deficient condition affected the normal growth of biomass in the activated sludge.

Table 1: $\quad$ Polymer production under different $\mathrm{C}: \mathrm{N}$ ratio.

\begin{tabular}{|c|c|c|c|c|c|c|}
\hline C:N ratio & $\Delta \mathbf{c}(\mathbf{g})$ & $\Delta \mathbf{p}(\mathbf{g})$ & $\Delta \mathbf{C O D}(\mathbf{g})$ & $\mathbf{Y}_{\mathbf{p} / \mathbf{c}}$ & $\mathbf{Y}_{\mathbf{c} / \mathbf{C O D}}$ & $\mathbf{Y}_{\mathbf{p} / \mathbf{C O D}}$ \\
\hline 24 & 1.79 & 0.11 & 2.79 & 0.06 & 0.64 & 0.04 \\
48 & 1.57 & 0.16 & 2.74 & 0.10 & 0.57 & 0.06 \\
96 & 0.96 & 0.23 & 2.48 & 0.24 & 0.39 & 0.09 \\
144 & 0.73 & 0.20 & 2.39 & 0.27 & 0.31 & 0.08 \\
\hline
\end{tabular}

$\Delta \mathrm{c}=$ net cell growth in dry cell mass during the 2-hour reaction time.

$\Delta p=$ net accumulation of polymers during the 2-hour reaction time.

$\triangle \mathrm{COD}=$ net consumption of COD during the 2-hour reaction time.

$\mathrm{Y}_{\mathrm{p} / \mathrm{c}}=$ specific polymer yield per unit dry cell mass.

$\mathrm{Y}_{\mathrm{c} / \mathrm{COD}}=$ specific dry cell mass yield per unit COD consumed.

$\mathrm{Y}_{\mathrm{p} / \mathrm{COD}}=$ specific polymer yield per unit COD consumed.

During four groups of tests, the COD removal efficiency remained similar. The specific polymer yield, Yp/COD, is another useful indicator in microbial production of PHAs. A larger Yp/COD indicates that more PHAs accumulation and less carbon source is used. Yp/COD reached a maximum of $0.09 \mathrm{~g}$ polymer/g COD consumed under $\mathrm{C}: \mathrm{N}$ ratio of 96 . For economical PHA production, a high volumetric productivity is required because it is an important factor that determines the PHA production cost. Experiments show polymer production reached a maximum at a $\mathrm{C}: \mathrm{N}$ ratio of 96 . This result provides a valuable reference for industrial application of PHA production.

\subsection{Control of polymer composition}

In the study of controlling polymer composition, six sets of batch culture were carried out. Activated sludge was first cultivated with synthetic water in a SBR with 1.5 day hydraulic retention time (HRT) and 2-hour aeration period. In each batch, 7-8g polymer-free activated sludge were harvested and washed with distilled water to remove any residual nitrogenous matters. They were inoculated into an automatic fermenter of $3 \mathrm{~L}$ volume (Bioengineering Model ALF, Ruti/Switzerland). The fermenter was fed with a nitrogen-free medium and operated at $300 \mathrm{rpm}$ and $30^{\circ} \mathrm{C}$ for 48 hours. The $\mathrm{pH}$ was automatically maintained at 7.0. The nitrogen-free medium contained butyric acid $\left(\mathrm{C}_{4}\right)$ and valeric acid $\left(\mathrm{C}_{5}\right)$ as carbon sources, and supplementary trace minerals. In each batch, $C_{4}$ to $C_{5}$ weight ratios in the medium were respectively adjusted to 100:0, $80: 20,60: 40,40: 60,20: 80$ and $0: 100(\mathrm{~g} / \mathrm{g})$. 
Table 2 shows the effects of changes in $\mathrm{C}_{4}$ to $\mathrm{C}_{5}$ weight ratio in polymer produced by activated sludge. When butyric acid was used as sole carbon source, there was only $\mathrm{P}(3 \mathrm{HB})$ homopolymer produced. When valeric acid was used as the sole carbon source, the highest $3 \mathrm{HV}$ mole fraction in the polymer was accumulated. A linear relationship was achieved between $3 \mathrm{HV}$ mole fraction in the polymer and valeric acid concentration (Figure 5). Mechanical and physical properties of polymer varied with ratio of $3 \mathrm{HB}: 3 \mathrm{HV}$. The polymer produced by activated sludge contains more 3HB units and is more brittle (Chua et al. [7]). Plastics used in different fields of industry require diverse properties. If desiring a certain quality or property of a plastic product, polymer composition can be constituted by adjusting $\mathrm{C}_{4}$ to $\mathrm{C}_{5}$ weight ratio.

Table 2: $\quad$ Production of $\mathrm{P}(3 \mathrm{HB})$ and $\mathrm{P}(3 \mathrm{HB}-\mathrm{co}-3 \mathrm{HV})$ by activated sludge with different carbon source ratios of butyric and valeric acids.

\begin{tabular}{|c|c|c|}
\hline $\mathbf{C}_{\mathbf{4}}$ to $\mathbf{C}_{\mathbf{5}}(\mathbf{g} / \mathbf{g})$ & COD removal (\%) & 3HV fraction (mol\%) \\
\hline $100: 0$ & 98.0 & 0 \\
$80: 20$ & 96.0 & 11 \\
$60: 40$ & 95.0 & 27 \\
$40: 60$ & 90.2 & 33 \\
$20: 80$ & 83.4 & 41 \\
$0: 100$ & 65.0 & 43 \\
\hline
\end{tabular}

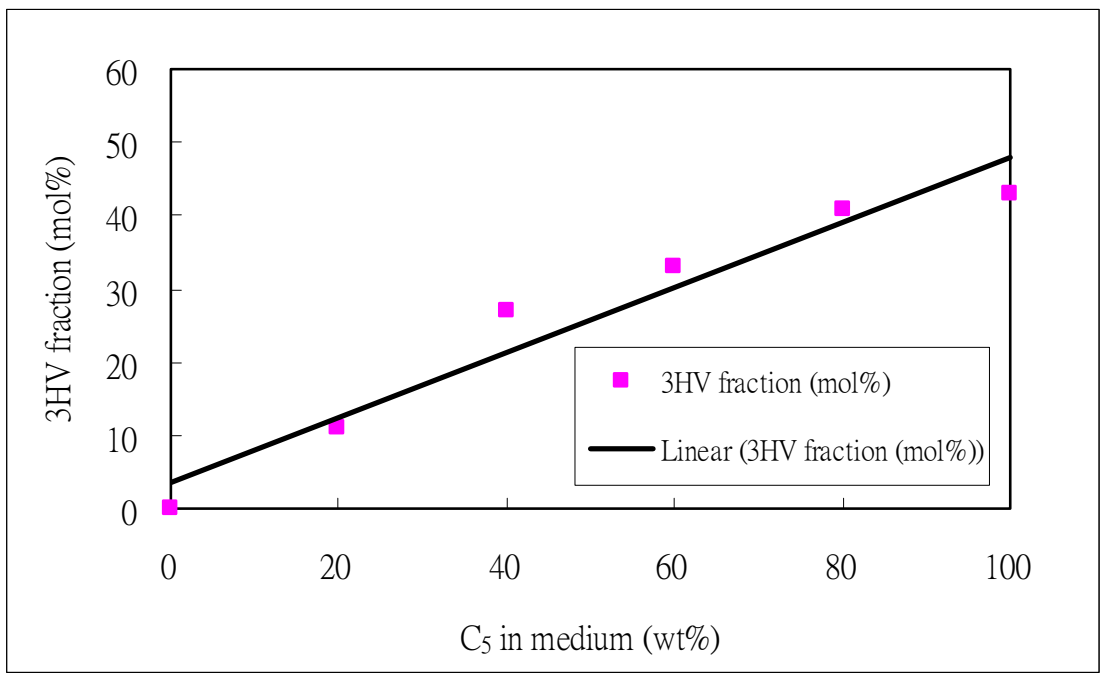

Figure 5: $\quad$ Relationship between $3 \mathrm{HV}$ fraction in $\mathrm{P}(3 \mathrm{HB}-\mathrm{co}-3 \mathrm{HV})$ and valeric acid concentration in the medium. 


\section{Conclusion}

Based on the observed activity of activated sludge in a laboratory SBR, the following conclusions can be drawn:

- As the C:N ratio increased from 24 to 144 , an optimum polymer production yield of $0.09 \mathrm{~g}$ polymer/g COD has been found under $\mathrm{C}: \mathrm{N}$ ratio of 96 , without significantly affecting organic treatment efficiency. This could represent an important step towards PHAs cost reduction.

- The composition of polymers could be controlled by manipulation of the carbon sources in the feed.

\section{Acknowledgements}

The authors gratefully thank the Research Grants Council, the Hong Kong Polytechnic University Central Research Grant and ITC (UIT/083) for the financial support.

\section{Reference}

[1] Huang, T., Zhao, J. Q. and Shen, J. R., The progress in microbiodegradable plastics, Plastic Industry, 4, 23-27, 1991.

[2] Lee, S. Y., Plastic bacteria progress and prospects for polyhydroxyalkanoates production in bacteria. Tibtech, 14, 431-8, 1996.

[3] Wang, F., Lee, S.Y., Poly(3-hydroxybutyrate) production with high polymer content by fed-batch culture of Alkaligenes latus under nitrogen limitation, Appl Environ Microbiol, 63, 3703-6, 1997.

[4] Lee, S. Y., Chang, H. N., Effect of complex nitrogen source on the synthesis and accumulation of poly(3-hydroxybutyric acid) by recombinant Escherichia coli in flask and fed-batch culture, J Environ Polym Degrad, 2, 169-76, 1994.

[5] Clesceri, L. S., Greenberg, A. E., Eaton, A. D., Standard methods for the examination of water and wastewater, American Public Health Association, 1998.

[6] Jan, S., Roblot, C., Goethals, G., Courtois, J., Courtois, B., Saucedo, J., Seguin, J. P., Barbotin, J. N., Study of parameters affecting poly(3hydroxybutyrate) quantification by gas-chromatography, Analytical biochemistry, 2, 258-263, 1995.

[7] Chua, H., Yu, P. H. F., Ma, C. K., Accumulation of biopolymers in activated sludge biomass, Appl Bioche Biotech, 77-79, 1999. 